A N N A L E S

UNIVERSITATIS MARIAE CURIE-SKŁODOWSKA

LUBLIN - POLONIA

VOL. LXVI, 1

SECTIO G

2019

Uniwersytet Rzeszowski

\author{
ARTUR ŁUSZCZYŃSKI \\ pan.artur.luszczynski@gmail.com \\ ORCID: 0000-0002-1589-935X
}

\title{
Wolność w myśleniu Tomasza G. Masaryka
}

Freedom in Political Thought of Thomas G. Masaryk

Spuścizna intelektualna Tomasza G. Masaryka jest dla życia społecznego naszych południowych sąsiadów żywa do dnia dzisiejszego ${ }^{1}$. Jego tezy były i są punktem odniesienia pomagającym rozstrzygnąć dylematy życia politycznego. Osoba Prezydenta Oswobodziciela stała się dla wielu ludzi ikoną międzywojennej demokracji, a po zakończeniu II wojny światowej była ideałem dążeń wolnościowych ${ }^{2}$.

W związku z powyższym zasadna i ciekawa poznawczo wydaje się analiza, czym była dla czeskiego filozofa kategoria wolności. Wyprzedzając nieco tok narracji, stwierdzę, że wolność i problemy, które pojęcie to implikuje, są właściwie nieobecne w Masarykowym myśleniu. Aby teza poprzedniego zdania nie budziła u czytelnika już na wstępie niepotrzebnego oporu, wyrażę ją inaczej wolność w pisarstwie czeskiego polityka zawiera w sobie tyle antynomii, że nie sposób precyzyjnie określić jej kształt. Co za tym idzie próby podejmowane przez różnych autorów, zmierzające do nakreślenia, czym dla Masaryka była wolność, mogą być zupełnie rozbieżne.

Za taki stan rzeczy odpowiedzialne są co najmniej dwa powiązane ze sobą problemy. Po pierwsze, Masarykowa narracja nie zawiera czytelnych wskazówek,

1 Jeszcze w 2000 r. osoba Masaryka stanowiła tło konfliktu pomiędzy Václavem Klausem a Václavem Havlem. Zob. V. Klaus, Masaryk a jeho obraz v dnešni české společnosti, „Spory o dějiny. Sborník kritických textů" 2000, nr 3, s. 169-173; L. Brokl, Masarykưv mýtus v pojetí Václava Klause, „Spory o dějiny. Sborník kritických textů” 2000, nr 3, s. 142-148; E. Broklová, Masaryk Klausem viděný, „Spory o dějiny. Sborník kritických textů” 2000, nr 3, s. 24-43.

2 Na taki stan rzeczy złożyło się wiele czynników, m.in. słynny wyrok Karla R. Poppera, iż Masaryk to ,jeden z największych bojowników o społeczeństwo otwarte”. Zob. K.R. Popper, Społeczeństwo otwarte i jego wrogowie, t. 2, Warszawa 1993, s. 59. 
definicji. $Z$ jednej strony stworzony jest pewien wewnętrznie logiczny system, z drugiej jednak wzajemne warunkowanie wygłoszonych sądów często zawodzi. Na ową „otwartość” filozofii Masaryka wskazywało wielu autorów. Karel Kramář, zwracając się do autora Ścieżek demokracji, stwierdził: „Wspominacie o różnych problemach, ale żadnego nie przemyśleliście do końca. Jednakże każdy, kto

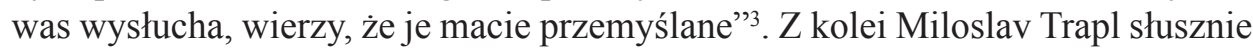
dodał: „Zarówno w filozofii, jak i polityce Masaryk nie dał nigdy systematycznego, kompletnego wykładu" ". Owa „otwartość” wypowiadanych sądów sprawia, że przy braku konkretnych wypowiedzi na temat wolności często mamy do czynienia ze zjawiskiem „nadpisywania” treści ${ }^{5}$. Innymi słowy, przyjęcie pewnych apriorycznych założeń wymusza przypisanie określonych twierdzeń Masarykowi. Posłużmy się przykładem. Jeżeli uznamy, że swoimi działaniami przed i podczas I wojny światowej Masaryk przywrócił Czechom wolność, następnie zaś stanął na czele demokratycznego państwa otoczonego morzem reżimów autokratycznych czy totalitarnych, to w naturalny sposób będziemy skłonni stwierdzić, że Prezydent Oswobodziciel musiał być zwolennikiem wolności ${ }^{6}$. W dalszej części wykażę, że jest to prawda częściowa lub prawda w pewnym kontekście.

Drugi problem wiąże się z wieloznacznością samego terminu „wolność”7. W tej kwestii Masaryk zdawał się nie przekraczać świata antycznych wyobrażeń i stworzonych wówczas klasycznych koncepcji. Tym samym podzielam sąd Josefa L. Hromádki, że Masarykowa filozofia świadomie pozostaje w antyku i średniowieczu, nie przyjmuje „nowoczesnego axiomu”. W bardzo wielu momentach Masaryk wyrażał przekonanie o powinności ścisłego powiązania wolnego wyboru z rozumowo rozpoznanym dobrem. Pisał: „Etyce jest podporządkowany

3 K. Kramář, Paměti, Praha 1938, s. 85.

4 M. Trapl, Védecké základy Masarykovy polityky, Brno 1946, s. 26. W polskiej literaturze przedmiotu taki sąd potwierdza Tadeusz J. Kroński (Ferdinand Pelikan: La Pensée de T.G. Masaryk, „Przegląd Filozoficzny” 1938, nr 4, s. 433): ,[...] w pismach Masaryka nie ma jakiegoś drogowskazu umożliwiającego dobitne unaocznienie problematyki, która go zajmowała i której dał określone rozwiązanie".

5 Skądinąd zachęcał do tego sam Masaryk, mówiąc: „Kto umie czytać, znajdzie mnie w mych pracach między wersami”. Zob. K. Čapek, Hovory s T.G. Masarykem, Praha 1946, s. 88.

6 Tego zabiegu dokonuje m.in. Władysław M. Kozłowski, pisząc we wstępie do Rewolucji światowej: ,[...] postulaty p. Masaryka popierały nie tylko interes narodu czeskiego, ale wszystkich innych narodów ujarzmionych, argumenta zaś jego, wobec tej bezwzględnej obiektywności, trafiały do przekonania przedstawicieli każdego narodu, niezaślepionego pangermanistycznym imperyalizmem. Wyróżnia akcyę jego i ta okoliczność, że filozofia polityczna, o którą się ona wsparła, ma za podstawę wymagania etyczne, a znamionowały ją bezwzględne poszanowanie wolności i wysoka tolerancja względem przeciwników”. Zob. T.G. Masaryk, Rewolucya światowa, t. 1, Warszawa-Poznań-Kraków-Lwów-Stanisławów [ca. 1930], s. 6.

7 Zob. R. Legutko, Wolność, [w:] Słownik społeczny, red. B. Szlachta, Kraków 2004, s. $1574 \mathrm{i} \mathrm{n.}$

8 J.L. Hromádka, Několik drobtů, [w:] T.G.M. jak jsme ho vidĕli, Praha 1948, s. 183. 
każdy człowiek w całości, wszystko, co przeżywa, co robi [...]"9. W jaki sposób zatem uzgodnić wolnościowe postulaty wyrażane przez myślicieli liberalnych i, co ważniejsze, pogodzić wpisanie owych postulatów w myślenie demokratyczne ze starożytnym przekonaniem, iż wolność jest w istocie koniecznością moralnych życiowych wyborów?

Zatrzymajmy się przez moment i spójrzmy na intelektualne inspiracje czeskiego filozofa. Wśród nich znajdziemy m.in. Platona, o którym czytamy: ,[...] filozof, który wpłynął na mnie najsilniej, to Platon. Głównie swoim podejściem do kwestii religijności, etyki i polityki oraz tą wyjątkową kombinacją teorii i praktyki”"10. Jeśli będziemy pamiętać, że dla greckiego filozofa niekontrolowana wolność wiedzie do anarchii i w końcowym efekcie do zniewolenia, to uświadomimy sobie jedno z istotnych źródeł niechęci Masaryka do poglądów liberalnych. Interesujące jest, z punktu widzenia mojej analizy, wymienienie wśród inspirujących myślicieli Johna S. Milla. W rozmowie z Karelem Čapkiem pada stwierdzenie: „Dalsze filozoficzne wpływy na mnie? Znaczące: Comte, Hume, Mill, przy czym nie wolno zapominać, że miewają na nas wpływ ludzie i autorzy, z którymi się nie zgadzamy" ". Chociaż prace Milla Zasady ekonomii politycznej i $O$ rządzie reprezentatywnym były Masarykowi znane, to osoba angielskiego filozofa została zredukowana do teorii poznania, tak jakby dzieło On Liberty nie było istotne ${ }^{12}$. Klasyczna fraza, że ,jedynym celem usprawiedliwiającym ograniczenie przez ludzkość, indywidualnie lub zbiorowo, swobody działania jakiegokolwiek człowieka jest samoobrona [...]", została pozostawiona bez komentarza ${ }^{13}$.

Zasadna wydaje się teza, że to właśnie zakorzenienie w antycznym postrzeganiu świata zjawisk społecznych rzutowało na postrzeganie przez Masaryka rzeczywistości mu współczesnej. „Indywidualizm” i „wolność jednostki”, coraz wyraźniej dochodzące do głosu na przełomie XIX i XX w., były terminami właściwie obcymi dla starożytnych.

W kwestii indywidualizmu Masaryk nie był konsekwentny, upatrując w nim drogi do groźnego „ubóstwienia człowieka”. W Ideałach humanizmu podkreślał:

Każdy indywidualizm skrajny uważam za błędny z tego prostego powodu, że żadna jednostka (ego) nie istnieje i nie może istnieć samotnie. [...] Człowiek nie jest Bogiem. Co to za Najwyższa istota, która urodziła się w rodzinie i wyrosła w społeczeństwie? Jedynie teoretyzująca krótko-

9 K. Čapek, op. cit., s. 122.

10 Ibidem, s. 41. Zapewnienie o platońskich inspiracjach znajdziemy też w innych dziełach. Por. T.G. Masaryk, Zwycięztwo idei wolnościowej narodu, Warszawa-Poznań-Kraków-Lwów-Stanisławów [b.d.w.], s. 452: „Plato był mym pierwszym i głównym nauczycielem politycznym”.

11 K. Čapek, op. cit., s. 43. Podobnie: T.G. Masaryk, Rewolucya ..., s. 156: „Z nowszych filozofów sympatycznym był dla mnie J.S. Mill (to w pewnej mierze także comte'ysta), jako przedstawiciel empiryzmu angielskiego".

12 Szerzej: R. Hain, Teorie státu a státní právo v myšleni T.G. Masaryka, Praha 2006, s. 60.

13 J.S. Mill, $O$ wolności, Warszawa 1999, s. 25. 
wzroczność [...] może izolować jednostkę od relacji z innymi jednostkami. Nie istnieje ,ja” samo w sobie i dla siebie. Skrajny indywidualizm załamuje się moralnie i teoretycznie, ponieważ umieszcza pojedynczego człowieka na równi z Bogiem ${ }^{14}$.

Dopuszczał natomiast istnienie pożytecznych form indywidualizmu: „Indywidualizm umiarkowany, prawdziwie filozoficzny i etyczny, pożąda, aby w społeczeństwie wspólnym wysiłkiem i na gruncie miłości rozwijać różne typy, charaktery i osobowości" ${ }^{15}$. Jak nadmieniłem, niekonsekwencja Masaryka w postrzeganiu indywidualizmu jest szczególnie widoczna, gdy idea ta jest przez niego omawiana przez pryzmat demokracji. Wówczas argumentacja, którą stosował do tej pory, niejako przestaje obowiązywać. Czytamy: „Demokracja, z koniecznością i przez swą własną podstawę, broni indywidualizmu - wolność jest celem i zasadą demokracji; demokracja powstała i istnieje dzięki nowożytnemu indywidualizmowi"16. Chociaż w filozofii Masaryka silne jest przekonanie o podmiotowości człowieka, to nigdy nie dochodzi do takiego zespolenia wolności i indywidualizmu, by zbliżyć się do poglądów liberalnych. Przytoczony wyżej cytat już kilkanaście stron dalej zostaje „skorygowany” twierdzeniem: „Demokracja spoczywa na indywidualizmie, ale indywidualizm nie oznacza samowoli, tylko dążenie do silnej indywidualności, nie tylko własnej, ale i pozostałych obywateli’' ${ }^{17}$. Widzimy zatem, że zdaniem czeskiego filozofa wolność, na wzór antyczny, musi podlegać samoograniczeniu. Podobny tok rozumowania pojawia się w Rozmowach, gdzie pada stwierdzenie:

Podstawową rzeczą jest starać się o siebie, kontrolować i doskonalić siebie samego. [...] To nie jest egoizm, wręcz przeciwnie. Być samodzielnym, samorządnym i samowystarczalnym to naprawdę oznacza nie żądać od drugiego, aby ci dawał to, co możesz osiągnąć sam. [...] Zawsze chciałem, żeby każdy był sam sobie Panem. Ma to znaczenie polityczne, socjalne i moralne. Być sobie Panem: to obejmuje wolność i dyscyplinę ${ }^{18}$.

Zwróćmy w tym miejscu uwagę na problem, o którym pisałem na wstępie - „nadpisywania” treści do Masarykowego wywodu po przyjęciu określonych założeń. Jest rzeczą powszechnie znaną, że nazwisko czeskiego myśliciela funkcjonowało dosyć długo jako tego, który dokonał pierwszej poważnej krytyki marksizmu. Co ciekawe, dla wielu czytelników lektura Kwestii społecznej, wydanej po niemiecku w 1899 r., była pierwotną w stosunku do lektury dzieł samego Karola Marksa. Jeżeli rozpoczęlibyśmy poznawanie Masarykowej filozofii od wskazanego dzieła, to z łatwością doszlibyśmy do wniosku, że jest on zwolennikiem

14 T.G. Masaryk, The Ideals of Humanity and How to Work, London [1938], s. 51.

15 Ibidem.

16 Idem, Zwycięztwo idei..., s. 614.

17 Ibidem, s. 654.

18 K. Čapek, op. cit., s. 60. 
indywidualizmu (sic!). Krytykując bowiem idee kolektywne, Masaryk sprawia wrażenie popierania koncepcji przeciwnej. W Ideałach humanizmu czytamy:

Materializm historyczny lub ekonomiczny prowadzi do kolejnych konkluzji. Najważniejsza brzmi, proletariat jest odrębną jednostką (the real individual) i nie pojedynczy człowiek, pojedynczy proletariusz i nie proletariat jednego narodu, ale całej ludzkości. Stąd pochodzi marksistowskie hasło: Proletariusze wszystkich krajów, łączcie się! To oznacza indywiduum, jednostkowe ego nie ma znaczenia wobec masy ${ }^{19}$.

\section{Następnie dodaje:}

Socjalizm [...] jest celowo antyindywidualistyczny. [...] opinia i świadomość jednostki nic nie znaczą; jaką wagę ma ostatecznie opinia jednostki w konfrontacji z masą, na przykład masą proletariacką. Ponieważ proletariuszy jest więcej niźli kapitalistów, interesy ludzkości, zgodnie z zasadą większości głosów, są reprezentowane przez masy proletariatu ${ }^{20}$.

Na podkreślenie zasługuje fakt, że Masaryk miał świadomość, iż idee tworzą się, mając za punkt wyjścia bądź to jednostkę, bądź grupę, jednakże jego próba poszukiwania w tej kwestii kompromisu nie wypada przekonująco ${ }^{21}$.

Rozstrzygając dylematy wolnościowe z perspektywy metafizycznej, Masaryk uznał istnienie wolnej woli ${ }^{22}$. Oznacza to, że zaaprobował istnienie determinizmu jako pewnego zapisanego porządku, zarówno w świecie fizycznym, jak i społecznym, dotyczącym też praw jego rozwoju, ale „,determinizm nie wyłącza wolności”. Wyjaśnienie jest następujące: ,[...] wolność i predestynacja (předurčenost) człowieka są określone jego stosunkiem do Boga wszechmocnego i wszystkowiedzącego [...]. Człowiek jest stworzony na obraz i podobieństwo Boga; z tego wypływa dla człowieka synergizm, współdziałanie z wolą Bożą"23. Człowiek jest więc wolny w pewnym określonym zakresie, przy czym owo ograniczenie wynika z praw wyższego rzędu, które jednocześnie są wpisane w istotę człowieczeństwa. Odczuwanie synergii z Bożą wolą tworzy „pokój wolności i determinizmu”. „Determinizm nie oznacza zniewolenia, przeciwnie"24 - człowiek pozostaje „,istnieniem autonomicznym” względem Boga, posiada inicjatywę i związaną

19 T.G. Masaryk, The Ideals of Humanity..., s. 25.

20 Ibidem.

21 Masaryk (ibidem, s. 26) pisze: „,...] jeśli jednostka nie ma żadnej wartości [...], to skąd bierze się wartość tysięcy jednostek? Dlaczego jednostka jest niczym, a masy wszystkim? Ten dylemat implikuje każdy kolektywizm i musimy pamiętać, że jest to jedno z najbardziej palących pytań naszych czasów - konflikt pomiędzy indywidualizmem i kolektywizmem - formułowany narodowo, klerykalnie lub socjalistycznie".

22 Zob. J. Srovnal, Determinismus v Masarykově filosofii, [w:] T.G. Masaryk, idea demokracie a současné evropanství. Sborník mezinárodni vědecké konference konané v Praze 2.-4. března 2000, t. 1, Praha 2001, s. 97-108.

${ }^{23}$ K. Čapek, op. cit., s. 144.

24 Ibidem. 
z nią odpowiedzialność. Problem ten w Zwycięztwie idei wolnościowej narodu został rozwinięty w następujący sposób:

Z tego jednak, że Opatrzność dba o nas i o świat, nie wynika bynajmniej fatalizm nieczynności, lecz przeciwnie - optymizm synergizmu, ścisły nakaz jak najusilniejszej pracy, pracy dla idei. Tylko w ten sposób możemy oczekiwać owego tak zwanego szczęśliwego przypadku, owej wewnętrznej logiki dziejów i życia, a polegać na pomocy boskiej².

Swoje przekonania na ten temat Masaryk przedstawiał już w swoich wcześniejszych pracach, kreśląc zadania stojące przed narodem czeskim:

Dla mnie česká otázka jest zagadnieniem losów ludzkości, jest problemem świadomości. Wierzę [...], że historia narodu nie jest przypadkowa, ale objawia się w niej określony plan Opatrzności, a w związku z tym zadaniem historyka i filozofa, zadaniem każdego narodu, jest ten plan odczytać, poznać w nim swoje miejsce, a następnie według tegoż poznania postępować w pracy i polityce ${ }^{26}$.

Wyłączenie wolności człowieka wykluczałoby pojęcie grzechu, gdyż ten ma ścisły związek ze swobodą czynu; z kolei brak możliwości wyboru pomiędzy dobrem a złem negowałby człowieczeństwo. Jednocześnie Masaryk przywołuje nazwiska myślicieli piszących na temat predestynacji i wolnej woli (św. Augustyn, św. Tomasz, Martin Luter, Huldrych Zwingli, Jan Kalwin), opatrując to komentarzem: „[...] myślę, że wiedzie to donikąd”. Powtarza też swój pogląd: „Dla mnie z teizmu, z uznania teleologicznego porządku świata, wypływa konsekwentnie determinizm"27.

Przechodząc do kolejnej płaszczyzny, na której dylematy wolnościowe są podejmowane przez Masaryka, należałoby skierować wzrok na wolność państwa i narodu. Jest paradoksem dziejów, że człowiek, który w znacznym stopniu przyczynił się do odzyskania przez Czechów niepodległości, w istocie nie uznawał tej kwestii za wiodącą. Jeszcze funkcjonując w ramach monarchii habsburskiej, kreśląc program działań politycznych, pisał:

Rozumie się samo przez się, że partie polityczne muszą za swój cel uznawać głoszenie prawa państwowego, przez co rozumiemy niepodległość. Jednakże chodzi o to, żeby głosiciele tych poglądów mieli świadomość środków wiodących do tego celu oraz by nie poprzestali jedynie na głoszeniu [...]. Niepodległość nie zachowa i nie zbawi żadnego narodu, naród sam musi utrzymać samodzielność - uratuje nas moralność i wykształcenie; polityczna niepodległość jest jedynie środkiem do prawego życia narodowego ${ }^{28}$.

25 T.G. Masaryk, Zwycięztwo idei..., s. 449.

${ }^{26}$ Idem, Česká otázka. Snahy a tužby národniho obrozeni, [w:] idem, Česká otázka. Naše nynějši krize. Jan Hus, Praha 2000, s. 11.

27 K. Čapek, op. cit., s. 145.

28 T.G. Masaryk, Česká otázka. Snahy..., s. 134. 
Jak łatwo zauważyć, jest to postawa zgoła odmienna od prezentowanej przez szereg działaczy politycznych w Polsce, gdzie hasła wolnościowe zostały na trwałe wpisane do katalogu cnót i celów narodu. Owo przesunięcie akcentów z niepodległościowych na kulturalne jest dla Masaryka symptomatyczne, tworzy ono bardzo charakterystyczny kontekst jego wypowiedzi ${ }^{29}$. Faktem jest, że Masaryk potrzeby wolności, niepodległości czy suwerenności państwowej nie negował, jednakże nigdy nie były to wartości same w sobie. Nietrudno się domyślić, że jego postawa była trudna do zaakceptowania przez jemu współczesnych, upatrujących w niej w najlepszym razie braku rozsądku politycznego. Jednakże autor Naszego obecnego kryzysu nieodmiennie powtarzał: ,[...] polityczna niepodległość może każdemu narodowi przynieść bardzo dużo korzyści, ale zyska najwięcej naród uświadomiony, wykształcony i moralny. Państwo nas nie zbawi, my musimy je utrzymać. Straciliśmy już jedno - dlaczego?"30.

Próbując w jakiś sposób zrekapitulować poglądy Masaryka dotyczące suwerenności jako rodzaju wolności, należałoby zwrócić uwagę na wspomniany już problem ,antyczności” podstaw jego rozumowania. Polega on na tym, że w milczący sposób uznawał on ludzką wolność za stan naturalny, przyrodzony. Jest to rodzaj paradygmatu, o którym nie ma sensu dywagować, gdyż cecha polityczności może mieć miejsce jedynie wówczas, gdy realizujące ją podmioty są wolne. Nad zakresem tej wolności można prowadzić rozważania, ale nie da się jej zakwestionować. W sytuacji, kiedy mamy do czynienia z kilkoma rodzajami wolności, wywód Masaryka może stać się nieczytelny, gdyż swojego paradygmatu on nie akcentuje. Co więcej, wszelkie wygłaszane przez niego sądy na temat wolności są przepuszczane przez pryzmat jego koncepcji historiozoficznych, metafizycznych i innych. Stwierdza on w jednym miejscu: „Problem suwerenności, czy to dotyczący jednostek, monarchów, czy też suwerenności państw i narodów, jest problemem o dużym znaczeniu”, by następnie dodać: „, [...] dziś absolutna suwerenność nie jest możliwa. Widzimy, że obecnie krok po kroku maleje absolutna suwerenność, gdyż powstaje coraz większa wzajemność (zależność) państw i narodów. [...] niezawisłość polityczna jest coraz bardziej relatywna"31.

Powyższego fragmentu nie sposób rozumieć literalnie, gdyż zawiera on w sobie przekonanie o postępującej demokratyzacji świata, zwycięstwie „czystego człowieczeństwa" nad siłami średniowiecznej teokracji. Dlatego w innym dziele stwierdził: „[...] spoczywać na wolności, równości i braterstwie, zarówno

29 W dziele Karela Havlička czytamy: „Żadna moc tego świata [...], nawet połączywszy swe siły z mocami piekielnymi, nie utrzyma narodu wykształconego, uświadomionego i uszlachetnionego w poddaństwie i niewolnictwie". Zob. idem, Karel Havliček: snahy a tužby politického probuzení, [w:] idem, Česká otázka. Naše nynější krize..., s. 208.

30 Idem, Naše nynějši krise: pád strany staročeské a počátkové směrů nových, [w:] idem, Česká otázka. Naše nynějši krize..., s. 183.

31 Idem, Student a politika, Praha 1990, s. 12-13. 
w stosunkach zewnętrznych, jak i wewnętrznych, będą tylko państwa nowe, naprawdę nowe, państwa przyszłości”32.

Być może właśnie próba kreślenia wolnościowych dylematów, obecnych w Masarykowej filozofii, z punktu widzenia historycznego rozwoju cywilizacji miałaby największy potencjał wyjaśniający. Musielibyśmy jednak w sposób bezkrytyczny podążać za wywodem czeskiego myśliciela, gdyż próba zgłaszania jakichkolwiek wątpliwości skończyłaby się sfalsyfikowaniem całej konstrukcji. Uważał on bowiem, że logika dziejów polega na stopniowym poszerzaniu sfery ludzkiej wolności, równości i człowieczeństwa ${ }^{33}$. Średniowieczny „arystokratyzm" przegrywa z nowożytnym demokratyzmem, a wojna światowa zdaje się ostateczną klęską tego pierwszego ${ }^{34}$. Czesi w tej odwiecznej walce powinni odegrać szczególną rolę, gdyż są dziedzicami Jana Husa, który jako jeden z pierwszych ową walkę rozpoczął. W dziele poświęconym osobie tego religijnego reformatora czytamy:

Reformacja z punktu widzenia jednostki nie byłaby możliwa bez uwolnienia społeczeństwa, wolności wyznania i politycznej. Z tego powodu Hus przeciwstawił się powadze kościelnej i papieskiej, która wówczas, chociaż upadała, była jeszcze wszechmocną. Wolność myślenia, wolność religijna w naturalny sposób prowadziły do uwolnienia spod mechanicznego kościelnego autorytetu. Reformacja osób wiodła ku reformie porządku społecznego - jedynie reforma osób jest reformacją ${ }^{35}$.

Uznanie reformacji za szczególny moment ludzkich dziejów, upatrywanie w niej tryumfu wolnego ducha sprawiło, że stosunek czeskiego filozofa do liberalizmu był konsekwentnie negatywny ${ }^{36}$. Jak słusznie pisał Josef Kaizl, liberalizm jest „określany [przez Masaryka] jako nieprzyjaciel”, nurt, który popierał kontrreformację ${ }^{37}$. Jednakże sprzeciw czeskiego filozofa wobec liberalnych koncepcji nie zasadzał się jedynie na uznaniu ich za przeciwnika sprzed kilkuset lat. Sądzę, że w krytycznym stosunku do liberalizmu zawiera się znacząca treść Masarykowej filozofii. Co istotne, argumenty wysuwane przez Masaryka przeciwko ideolo-

${ }^{32}$ Idem, Zwycięztwo idei..., s. 613.

33, „[...] prawdziwa polityka demokratyczna będzie się kształtowała również sub specie aeternitatis: absolutyzm duchowy, różne formy cezaropapizmu i absolutyzm świecki nadużywający religii, zostanie pokonany przez wyższą moralność, przez ludzkość i przez wyższą religię, rządzącą także życiem publicznym w sposób wolny - Jezus nie Cezar!” - ibidem, s. 636.

34 W pracy Student a politika (op. cit., s. 9) czytamy: „Istotą politycznego rozwoju jest demokratyzacja, ubywa arystokratyzmu [...]. Arystokratyzm nie jest jedynie politycznym. Arystokratyzm jest przede wszystkim religijnym, moralnym. [...] Może być i jest arystokratyzm narodowy, językowy i rasowy. [...] urzędniczy, wojskowy".

35 T.G. Masaryk, Česká otázka. Naše nynější..., s. 318.

36 Nie będę w tym miejscu szeroko komentował, na ile uprawnione jest posługiwanie się przez Masaryka terminem „liberalizm”. Zob. szerzej: A. Łuszczyński, Myśl polityczno-prawna Tomasza G. Masaryka jako rodzaj mitu państwotwórczego, Rzeszów 2013, s. 281-283.

37 J. Kaizl, České myšlénky, Praha 1896, s. 17. 
gii bądź co bądź wolnościowej, niezależnie od ich prawdziwości, noszą w sobie wiecznie żywy, archetypiczny obraz liberalizmu w oczach jego przeciwników. Warto im się przyjrzeć bliżej, gdyż historia idei pokazuje, że są one w jakiś sposób atemporalne - wypowiadane przed stu laty, w określonym kontekście historycznym, geograficznym, społecznym, ekonomicznym itd., często powracają tylko w nieznacznie zmienionej formie.

Jednym z podstawowych argumentów przeciwko liberalizmowi jest jego obcość względem idei czeskich. Nie będę w tym miejscu rozstrzygał, czy w przypadku myśli stosowanie klucza geograficznego ma w ogóle sens. Masaryk stał na stanowisku, że Czesi, podejmując trud emancypacji narodowej, stali się niezwykle podatni na idee, ,światowe”. Pisał:

Jest rzeczą zrozumiałą, że po długim duchowym śnie zasiadamy wygłodniali do suto zastawionego stołu światowej kultury. Chcemy uniknąć swojej niedostateczności i małości i w głodzie połykamy wszystko, co nam obcy oferują. Ale kto długo głodował, musi jeść ostrożnie i rozważnie ${ }^{38}$.

Zgodnie z własną wizją dziejów postulował, aby Czesi sięgnęli do skarbca własnej kultury i nie ulegali wpływom zewnętrznym:

Prawdziwy czeski człowiek, czeski człowiek myślący, chce mieć zwarty pogląd na życie, chce mieć teraźniejszość i przeszłość organicznie związane, chce mieć treść wszystkich swoich dążeń zgodną z podstawowymi ideami swej historii, z Bractwem, z Humanitą. Chce się kierować tą ideą nie dlatego, że jest czeska, ale dlatego, że jest słuszna, że jej nie sposób odrzuciććc

Liberalizm ze swoją wolnością jednostki, indywidualizmem, staje się więc ideą osłabiającą siły, których młody naród potrzebuje ${ }^{40}$.

Jakkolwiek argumentacja Masaryka miała często wymiar bieżącej walki politycznej, przez co stosowane środki były często spłycane, tak by łatwiej trafiały do niewykształconego odbiorcy, to jednocześnie dostrzegał on kuszącą siłę liberalizmu. Nie przypisywał mu jednak roli takiej, jaką miały socjalizm i nacjonalizm. Czytamy:

[...] stał się liberalizm filozofią naszego wieku - szczególnie żurnalistyka, służąca liberalnemu konstytucjonalizmowi, była i jest liberalna. Liberalizm jest wielkim kontraktem doby, utrzymać społeczność jako tako, na popsutych podstawach rewolucji, tu i tam nieco poprawić, gdzieniegdzie dotknąć [...], ale tylko dotknąć; żadnej dokładnej rewizji i reformy - oto hasło całego liberalizmu ${ }^{41}$.

38 T.G. Masaryk, Česká otázka. Naše nynější..., s. 331.

39 Ibidem, s. 332.

40 Masaryk (ibidem, s. 315) pisze: „Nasz program odrodzeniowy osłabia liberalizm, budzicielskie starania o oświatę i wykształcenie hamuje pozbawione świadomości, eklektyczne naśladowanie rozmaitych europejskich wzorów [...]. Idee owe mamy na papierze - w rzeczywistości się nimi nie kierujemy".

${ }^{41}$ Ibidem, s. 316. Fraza „popsute podstawy rewolucji” odnosi się do źródeł liberalizmu czerpiącego z rewolucji francuskiej, przez co zatraca on konieczny religijno-etyczny fundament: „Nasze 
Problemem dla Masaryka były również „liberalne” przekonania dwóch wielkich poprzedników - Franciszka Palackiego i Karela Havlíčka. Autor Jana Husa twierdził zatem, że liberalizm ma różne oblicza, a co za tym idzie jego krytyka była kierowana pod adresem tych „złych”. Pisał między innymi, że „tak jak dziś słowem "postępowy« opatrujemy różne prądy, tak wówczas słowo »liberalizm « było niejednoznaczne" ${ }^{2}$. Pojawia się więc kategoria "fałszywego liberalizmu”, przy czym w opozycji do niej trudno określić „liberalizm prawdziwy" ${ }^{\prime 4}$. Dla Czecha wartości proponowane przez liberalizm nie powinny być kuszące: „Prawdziwie czeski człowiek, czeski człowiek myślący, nie przyjmuje pustego nacjonalizmu i jałowego politykowania [...], nie chce eklektycznego i historycznego empiryzmu, dlatego że chce się pozbyć materializmu i łżeliberalizmu"44.

Fraza pojawiająca się w ostatnim zdaniu przywołanego wyżej odesłania wskazuje na kolejny z argumentów przeciwko liberalizmowi - kult pieniądza. Masaryk zakładał, że teoria ekonomiczna liberalizmu w prosty sposób była przenoszona na inne sfery życia społecznego. Wskazywał, że liberalizm ,wierzy jedynie w pieniądze", nie podawał jednak, skąd czerpie takie przekonanie ${ }^{45}$. W opozycji do tego zaproponował własną wizję, która przy uważnej lekturze nie wydaje się sprzeczna z krytykowanym liberalizmem:

[...] już od roku 1848 nasze hasło brzmi: bogaćmy się. Człowiek praktyczny nie będzie się temu sprzeciwiał. Bogacenie się nie może być jednak najwyższym życiowym celem. Rzeczą ważniejszą jest, jak bogactwo zostanie spożytkowane. Są ludzie, których jedynym pragnieniem jest być bogatym i są tym samym niewolnikami pieniądza. Chrystus powiedział, że jest Panem szabatu, każdy naród i każda jednostka powinny być panem swojego bogactwa. To oznacza, że nie możemy wyrażać zgody, by materializm nas zdominował, powinniśmy hołdować najlepszym zasadom religijnym i moralnym czy jakimkolwiek innym. Trzeba być panem swoich pieniędzy, zdobywać je w sposób uczciwy i szlachetnie wykorzystywać ${ }^{46}$.

Przypisywany liberalizmowi kult pieniądza oraz uznanie materializmu za jego fundament $\mathrm{w}$ naturalny sposób sprawiło, że pojawił się kolejny, być może najpoważniejszy, argument przeciwko tej doktrynie - amoralność. Według Masaryka „Liberalizm żywił i ciągle żywi niechęć do moralności. Wszyscy liberalni

braterstwo było naprawdę inne aniżeli »braterstwo« rewolucji francuskiej. Nasze braterstwo było założone na uczuciu i idei religijnej, braterstwo rewolucyjne było negacją religijnego uczucia, miało źródło w celu politycznym".

42 Idem, Karel Havliček..., s. 285.

43 Określenie „łżeliberalizm” pojawiło się również w pracy Nasz obecny kryzys. Zob. idem, Naše nynějši krise..., s. 277.

44 Idem, Česká otázka. Naše nynější..., s. 332.

45 Ibidem, s. 348. W innej pracy, krytykując partię staroczeską i starając się ją zdeprecjonować, Masaryk (Naše nynějš̉ krise ..., s. 178) pisał: „W sprawach ekonomicznych partia kierowała się czystym liberalizmem".

46 Idem, The Ideals of Humanity..., s. 33. 
teoretycy, szczególnie ekonomiści, odrzucali moralność wyraźnie i kategorycznie, są i byli nauczycielami marksistów" ${ }^{47}$. Próba liberalnego rozwiązania kwestii wolności religijnej spotkała się też z krytycznym odzewem Masaryka. Stwierdził, że „Liberalizm uznaje problem religii za ostatecznie rozwiązany w swoim duchu, jednakże myli się, negacja nie jest rozwiązaniem"48. Nie może zatem dziwić stwierdzenie, które znajduje się w Rozmowach: „Nie popierałem i nie popieram liberalizmu ze względu na religijną obojętność i powierzchowność"49. Z uwagi na to, że dla czeskiego myśliciela utrata prawdziwej wiary przez współczesnego mu człowieka była symptomem choroby wieku, pozostawienie kwestii religijnej osobistemu wyborowi (łącznie z prawem niewiary) było poważnym i niewybaczalnym błędem:

Liberalizm dzisiejszy omija istotne problemy, jak diabeł krzyż. Kwestia religijna jest dla liberała solą w oku. Zrozumiałe, liberał wierzy przede wszystkim we władzę polityczną i tym samym jedynie w materię, a trzeba, by przekonał się i do Chrystusa Pana, Pana Boga i przyjął wszystkie ideały ideałów. Nie oceniam jednostek, ale zasadę, typ. Są przecież, wiem to dobrze, różne stopnie liberalizmu ${ }^{50}$.

Wolność u Masaryka zawsze odgrywa rolę służebną względem innych wartości, czemu dał on wyraz nie tylko w sposób bezpośredni, ale również określając swój stosunek do idei mających wolność u swoich fundamentów, czyli do liberalizmu i anarchizmu. O tym drugim pisał m.in.:

Demokracja przez swą istotę przeciwna jest wszelkiemu anarchizmowi [...]. Anarchizm występuje przeciw demokracji w imię wolności, tej idei podstawowej demokracji. [...] Bronię demokracji konsekwentnie przeciw anarchizmowi wszelkich rodzajów. Każdy człowiek naturalnie tęskni za wolnością, państwo zaś ma tęsknotę tę szanować; ale z historii czerpię tę wiedzę, że społeczeństwo było zawsze państwowo zorganizowane ${ }^{51}$.

Jak można zorientować się z powyższego fragmentu, moja teza wyrażona na wstępie wydaje się prawdziwa. Masaryk - tak jak każdy inny myśliciel snujący rozważania dotyczące świata zjawisk społecznych, w których mamy do czynienia z władzą - musiał zmierzyć się z dylematem wolności. Jednakże owa wolność, co z różnych powodów zakrawa na paradoks, nie stała w centrum. Dla demokracji, którą proponował czeski mąż stanu, ważniejszą kategorią była etyka ${ }^{52}$. Rozumie-

47 Ibidem.

48 Idem, Česká otázka. Naše nynější.., s. 317. W innym miejscu dodaje: „[...] naszym czeskim celom sprzeciwia się liberalny indyferentyzm" - ibidem, s. 347.

49 K. Čapek, op. cit., s. 82.

50 T.G. Masaryk, Česká otázka. Naše nynější..., s. 347-348.

51 Idem, Zwycięztwo idei..., s. 650-651.

52 Faktem jest, że w czasach istnienia Republiki można znaleźć stwierdzenia Masaryka, które można odczytywać jako rodzaj „rehabilitacji” wolności. W przemówieniu skierowanym do armii 
jąc źródła takiej postawy, można zadać zasadne pytanie: Czy limitowanie ludzkiej wolności moralnością, która nigdy nie będzie miała charakteru uniwersalnego, nie godzi w samą wolność? Czy tym samym teza wyrażona przez Aleksandra Hercena w zdaniu: „[...] podporządkowanie jednostki społeczeństwu, narodowi, ludzkości, idei - to kontynuacja składania ofiar z ludzi, to zarżnięcie jagnięcia dla przebłagania Boga, ukrzyżowanie niewinnego za winnych" - nie zostaje potwierdzona? $?^{53}$

\section{BIBLIOGRAFIA}

Brokl L., Masarykưv mýtus v pojetí Václava Klause, „Spory o dějiny. Sborník kritických textů” $2000, \mathrm{nr} 3$.

Broklová E., Masaryk Klausem viděný, „Spory o dějiny. Sborník kritických textů” 2000, nr 3.

Čapek K., Hovory s T.G. Masarykem, Praha 1946.

Hain R., Teorie státu a státní právo v myšleni T.G. Masaryka, Praha 2006.

Hercen A., Pisma filozoficzne, t. 1, Warszawa 1965.

Hromádka J.L., Několik drobtů, [w:] T.G.M. jak jsme ho viděli, Praha 1948.

Kaizl J., České myšlénky, Praha 1896.

Klaus V., Masaryk a jeho obraz v dnešni české společnosti, „Spory o dějiny. Sborník kritických textư" 2000, $\mathrm{nr} 3$.

Kramáŕ K., Pamĕti, Praha 1938.

Kroński T.J., Ferdinand Pelikan: La Pensée de T.G. Masaryk, „Przegląd Filozoficzny” 1938, nr 4.

Legutko R., Wolność, [w:] Słownik społeczny, red. B. Szlachta, Kraków 2004.

Łuszczyński A., Myśl polityczno-prawna Tomasza G. Masaryka jako rodzaj mitu państwotwórczego, Rzeszów 2013.

Masaryk T.G., Armádě, [w:] idem, Cesta demokracie. Soubor projevů za Republiky 1921-1923, t. 2, Praha 1938.

Masaryk T.G., Česká otázka. Naše nynějši krize. Jan Hus, Praha 2000.

Masaryk T.G., Česká otázka. Snahy a tužby národního obrození, [w:] idem, Česká otázka. Naše nynějši krize. Jan Hus, Praha 2000.

Masaryk T.G., Karel Havliček: snahy a tužby politického probuzeni, [w:] idem, Česká otázka. Naše nynějši krize. Jan Hus, Praha 2000.

Masaryk T.G., Naše nynějši krise: pád strany staročeské a počátkové směrů nových, [w:] idem, Česká otázka. Naše nynějši krize. Jan Hus, Praha 2000.

Masaryk T.G., Rewolucya światowa, t. 1, Warszawa-Poznań-Kraków-Lwów-Stanisławów [ca. 1930].

Masaryk T.G., Student a politika, Praha 1990.

Masaryk T.G., The Ideals of Humanity and How to Work, London [1938].

Masaryk T.G., Zwycięztwo idei wolnościowej narodu, Warszawa-Poznań-Kraków-Lwów-Stanisławów [b.d.w.].

Mill J.S., O wolności, Warszawa 1999.

padają słowa: „Żołnierz ma wielkie moralne powołanie; jest zawsze na straży i jest jako pierwszy wezwany, by w przypadku zagrożenia oddać życie za państwo i jego ideały; te ideały demokratycznej republiki kryją się w haśle - wolność. Wolność w całym zakresie społecznych dążeń: narodowych, socjalnych i, ogólnie biorąc, kulturowych" - idem, Armádè, [w:] idem, Cesta demokracie. Soubor projevi za Republiky 1921-1923, t. 2, Praha 1938, s. 402.

${ }_{53}$ A. Hercen, Pisma filozoficzne, t. 1, Warszawa 1965, s. 662. 
Popper K.R., Społeczeństwo otwarte i jego wrogowie, t. 2, Warszawa 1993.

Srovnal J., Determinismus v Masarykově filosofii, [w:] T.G. Masaryk, idea demokracie a současné evropanství. Sborník mezinárodní védecké konference konané v Praze 2.-4. března 2000, t. 1, Praha 2001.

Trapl M., Vědecké základy Masarykovy polityky, Brno 1946.

\section{SUMMARY}

The article analyzes paradoxes concerning the notion of freedom in Thomas G. Masaryk's political philosophy. The Czech president and statesman has become a symbol not only for his countrymen but also personified the democratic ideal for citizens of many countries of Central and Eastern Europe, the United States and Western Europe. However, his "democratism" had very special marks, making it easy to misinterpret the ideas he proclaimed. Masaryk expressed his conviction about the duty of strict linking of free choice with a reasonably recognized good, which transferred the center of gravity in defining the democratic system from liberalism to ethics.

Keywords: Thomas G. Masaryk; freedom; political thought

\section{STRESZCZENIE}

W artykule przeprowadzono analizę paradoksów dotyczących pojęcia wolności, występujących w filozofii politycznej Tomasza G. Masaryka. Czeski prezydent i mąż stanu stał się symbolem nie tylko dla swoich rodaków, ale też uosabiał demokratyczny ideał dla obywateli wielu krajów Europy Środkowo-Wschodniej, Stanów Zjednoczonych i Europy Zachodniej. Jednakże jego „demokratyzm" nosił bardzo szczególne znamiona, przez co łatwo o błędy w interpretacji głoszonych przez niego idei. Masaryk wyrażał przekonanie o powinności ścisłego powiązania wolnego wyboru z rozumowo rozpoznanym dobrem, co przenosiło środek ciężkości w definiowaniu systemu demokratycznego z liberalizmu na etykę.

Słowa kluczowe: Tomasz G. Masaryk; wolność; myśl polityczna 